\title{
Pengaruh Profitabilitas, Ukuran Perusahaan, dan Leverage Terhadap Perataan Laba pada Perusahaan Manufaktur di BEI
}

\author{
(The Effect Of Profitability, Firm Size And Leverage \\ to The Income Smoothing In Manufactur Industies on BEI) \\ Tria Oktaviasari ${ }^{*}$, Muhammad Miqdad, Rochman Effendi \\ Jurusan Akuntansi, Fakultas Ekonomi dan Bisnis, Universitas Jember (UNEJ) \\ Jln. Kalimantan 37, Jember 68121 \\ E-mail: tria_oktaviasari@yahoo.com
}

\begin{abstract}
Abstrak
Penelitian ini bertujuan untuk mengetahui pengaruh profitabilitas, ukuran perusahaan, dan leverage terhadap perataan laba. Penelitian ini menggunakan data sekunder yang diperoleh dari Bursa Efek Indonesia pada tahun 2011-2015. Metode analisis data menggunakan Statistik Deskriptif, Uji Asumsi Klasik, dan Pengujian Hipotesis yang terdiri dari Metode Regresi Linier Berganda, Koefisien Determinasi, Uji F, serta Uji t. Hasil penelitian menunjukkan hubungan yang signifikan antara profitabilitas, ukuran perusahaan, dan leverage terhadap perataan laba. Hasil ini membuktikan bahwa profitabilitas, ukuran perusahaan, dan leverage mampu memberikan pengaruh untuk melakukan tindakan perataan laba. Perataan laba dilakukan untuk menunjukkan kestabilan laba perusahaan setiap periodenya sehingga akan meningkatkan minat investor untuk berinvestasi.
\end{abstract}

Kata Kunci: Perataan laba, Profitabilitas, Ukuran perusahaan, Leverage

\begin{abstract}
This research aims to determine the effect of profitability, company size, and leverage on income smoothing. This research used secondary data obtained from the Indonesia Stock Exchange in 2011 to 2015. Methods of data analysis using descriptive statistics, Classical Assumption Test, and Hypothesis Testing consists of Multiple Linear Regression method, F test, $\mathrm{t}$ test, and coefficient of determination. The results showed a significant relationship between profitability, company size, and leverage on income smoothing. This result proves that profitability, company size, and leverage able to give effect to the income smoothing. Income smoothing conducted to showed the stability of the company's profit in each period so that will increase the interest of investors to invest.
\end{abstract}

Keywords: Income smoothing, profitability, size of company, Leverage

\section{Pendahuluan}

Saat ini perekonomian di Indonesia telah memasuki era yang berkembang, sehingga perusahaan-perusahaan yang ada mulai berusaha menjadikan sebagai perusahaan go publik. Di lihat dari perkembangan jumlah perusahaan go publik yang terdaftar di BEI dari tahun ke tahun mengalami peningkatan, tercatat hingga tahun 2016 berjumlah 532 perusahaan (Bursa Efek Indonesia, 2016). Adanya BEI perusahaan-perusahaan akan diuntungkan karena dapat mempublikasikan citra perusahaan sehingga berkesempatan menarik investor untuk bekerjasama.

Citra perusahaan akan tergambar salah satunya dengan melihat laporan keuangan perusahaan tersebut. Laporan keuangan adalah media utama bagi suatu entitas untuk mengkomunikasikan informasi keuangan oleh manajemen kepada para pemangku kepentingan. Laporan keuangan juga merupakan wujud pertanggung jawaban manajemen atas penggunaan sumber daya yang dipercayakan kepada mereka dalam mengelola suatu entitas. Untuk mencapai tujuan tersebut, laporan keuangan yang lengkap terdiri dari : laporan posisi keuangan, laporan laba rugi, laporan perubahan ekuitas, laporan arus kas, dan catatan atas laporan keuangan.

Laporan keuangan dianggap sebagai pandangan yang menunjukkan kinerja perusahaan, sehingga informasi apapun dapat terlihat di dalam laporan keuangan salah satu informasi terpenting yaitu laba. Namun pada kenyataannya, banyak perusahaan melakukan kecurangan dengan melakukan perataan laba. Perataan laba (income smoothing) adalah pengurangan fluktuasi dari tahun ke tahun dengan memindahkan pendapatan dari tahun-tahun yang tinggi pendapatannya ke periode-periode yang kurang menguntungkan (Belkaoui,2007).

Praktik Perataan laba merupakan fenomena yang telah banyak dilakukan di berbagai negara. Banyak yang memperdebatkan apakah perataan lama itu baik atau buruk, serta mengapa perataan laba ini banyak dan boleh dilakukan. Perataan laba tidak menjadi masalah untuk dilakukan selama dalam pelaksanaannya tidak mengandung fraud (Wijoyo, 2014). Disisi lain perataan laba dapat merugikan pihak-pihak yang berkepentingan terhadap perusahaan seperti investor maupun pemakai laporan keuangan. Pengungkapan informasi mengenai laba menjadi menyesatkan dan akan menyebabkan terjadinya kesalahan dalam pengambilan keputusan.

Perusahaan yang tercatat di BEI (Bursa Efek Indonesia) terbagi dalam beberapa sektor seperti sektor perbankan, keuangan, manufaktur dan sebagainya. Namun disini peneliti akan melakukan penelitian di sektor manufatur. Alwiyah dan Solihin (2015) menyatakan bahwa perusahaan manufaktur mendominasi perusahan terbanyak yang tecatat dalam Bursa Efek Indonesia. Hal tersebut menjadikan perusahaan manufaktur menjadi perusahaan yang menarik perhatian bagi

* Corresponding Author 
investor untuk melakukan investasi. Peneliti memilih sektor manufaktur dikarenakan berdasar jurnal dan penelitian terdahulu terdapat perbedaan pendapat mengenai hasil dari penelitian. Alasan lain dilakukannya penelitian karena periode data penelitian belum menunjukkan data terbaru. Ketidak konsistenan hasil dan ketidak updatean data tersebutlah maka peneliti ingin menguji kembali faktor-faktor yang berpengaruh tehadap perataan laba (Income Smoothing).

Berbeda dengan penelitian sebelumnya, penelitian ini menggunakan variabel independen untuk menguji faktorfaktor yang mempengaruhi keputusan perataan laba. Variabel yang digunakan ialah profitabilitas, ukuran perusahaan, dan leverage. Pemilihan variabel tersebut karena terdapat ketidakkonsistenan hasil penelitian terdahulu.

Profitabilitas merupakan keuntungan yang didapat dari hasil pengurangan modal perusahaan dan keputusan kebijakan perusahaan yang biasa kita sebut dengan biaya dan beban. Profitabilitas sendiri biasa digunakan oleh investor untuk mengukur tingkat ketercapaian dan kemampuan perusahaan menghasilkan laba. Menurut Sawir (2004) ukuran perusahaan dinyatakan sebagai determinan dari struktur keuangan dalam hampir setiap studi untuk alasan yang berbeda. Ukuran perusahaan dapat menentukan tingkat kemudahan perusahaan memperoleh dana dari pasar modal. Ukuran perusahaan juga dapat menentukan kekuatan tawar-menawar dalam kontrak keuangan. Leverage adalah analisis untuk mengukur sejauh mana aktiva perusahaan dibiayai dengan utang. Analisis ini digunakan untuk mengukur seberapa banyak dana yang disupplay oleh pemilik perusahaan dalam proporsinya dengan dana yang diperoleh dari kreditur perusahaan atau untuk mengukur sampai berapa jauh perusahaan telah dibiayai dengan utang-utang jangka panjang.

Berdasarkan latar belakang yang telah dipaparkan penelitian ini bertujuan untuk mengetahui pengaruh profitabilitas, ukuran perusahaan, dan leverage terhadap praktik perataan laba pada perusahaan manufaktur yang terdaftar di BEI.

\section{Metode}

\section{Rancangan atau Desain Penelitian}

Penelitian yang dilakukan merupakan penelitian yang menggunakan data sekunder berupa laporan keuangan perusahaan yang akan diteliti. Melakukan uji hipotesis dalam penelitiannya. Analisis dilakukan dengan menjelaskan hubungan variabel independen terhadap variabel dependen.

\section{Jenis dan Sumber Data}

Jenis data yang digunakan pada penelitian ini adalah data sekunder. Data sekunder merupakan data yang diperoleh dalam bentuk jadi, diolah, dan yang dipublikasikan. Data sekunder tersebut merupakan pooled data (penggabungan data) dari time series (data pengamatan suatu variable dikumpulkan berdasarkan waktu yang berbeda-beda) dan cross-section (data yang terdiri dari satu atau lebih variable yang dikumpulkan pada waktu yang sama). Data keuangan diperoleh dari laporan keuangan perusahaan manufaktur yang terdapat pada Indonesia Capital Market Directory (ICMD) dalam situs resmi BEI.

\section{Populasi dan Sampel}

Populasi yang digunakan pada penelitian ini ialah seluruh perusahaan manufaktur yang terdaftar di Bursa Efek Indonesia selama periode penelitian dari tahun 2011 hingga tahun 2015. Dari populasi yang ada akan digunakan dalam penelitian, namun sebelumnya akan dipilih dahulu sampel yang akan digunakan menggunakan teknik purposive sampling dengan kriteria sebagai berikut :

1. Perusahaan yang telah terdaftar di Bursa Efek Indonesia sampai dengan 31 Desember 2015 dan menerbitkan laporan keuangan per 31 Desember untuk periode 2011 2015.

2. Perusahaan yang laporan keuanganya mempunyai laba positif atau profit, karena penelitian ini bertujuan untuk melihat praktik perataan laba

3. Perusahaan manufaktur yang tidak melakukan akuisisi atau merger selama periode penelitian. Bila perusahaan melakukan akuisisi atau merger selama periode pengamatan akan mengakibatkan variabel-variabel dalam penelitian mengalami perubahan yang tidak sebanding dengan periode sebelumnya. Sedangkan bila perusahaan deslisting maka hasil penelitian tidak akan berguna karena perusahaan tersebut di masa mendatang tidak lagi tercatat.

\section{Hasil dan Pembahasan}

\section{Statistik deskriptif}

Statistik deskriptif digunakan untuk mengetahui karakteristik data layak atau tidak untuk digunakan. Hasil pengolahan data statistik deskriptif variabel penelitian tampak pada Tabel 1 berikut ini:

Tabel 1. Hasil Statistik Deskriptif

\begin{tabular}{|c|c|c|c|c|c|}
\hline Variabel Penelitian & $\mathrm{N}$ & Min & Max & Mean & $\begin{array}{l}\text { Standar } \\
\text { Deviasi }\end{array}$ \\
\hline Profitabilitas (X1) & 245 & 0,01 & 0,84 & $\begin{array}{c}0,132 \\
8\end{array}$ & 0.15706 \\
\hline $\begin{array}{l}\text { Ukuran Perusahaan } \\
\text { (X2) }\end{array}$ & 245 & 0,25 & 0,33 & $\begin{array}{c}0,286 \\
3\end{array}$ & 0.01755 \\
\hline Leverage (X3) & 245 & 0,10 & 0,88 & $\begin{array}{c}0,427 \\
8\end{array}$ & 0.17758 \\
\hline Perataan Laba (Y) & 245 & 0,01 & 0,61 & $\begin{array}{c}0,170 \\
3\end{array}$ & 0.11543 \\
\hline
\end{tabular}

\section{Sumber : Hasil output SPSS}

Berdasarkan Tabel 1 yang menyajikan statistik deskriptif data perusahaan manufaktur yang terdaftar di Bursa Efek Indonesia tahun 2011-2015, diketahui nilai minimum, nilai maksimum, dan rata-rata untuk masing-masing variabel dependen maupun variabel independen yaitu:

1. Berkaitan dengan variabel Perataan Laba yang bejumlah 245 data penelitian variabel perataan laba (Y) memiliki nilai rata-rata yang menyatakan rerata nilai dari perataan laba pada seluruh data yang ada sebesar 0,1703 dan standar deviasi yang menampilkan besarnya nilai simpangan baku pada perataan laba sebesar 0,11543. Adapun nilai minimum dari perataan laba sebesar 0,01 yang artinya dari seluruh data perusahaan manufaktur yang tercatat di BEI, perusahaan IPOL merupakan perusahaan paling kecil melakukan praktik perataan laba. 
Sedangkan nilai maksimum perataan laba sebesar 0,61 yang artinya dari seluruh data perusahaan manufaktur yang tercatat di BEI, perusahaan STAR merupakan perusahaan paling besar melakukan praktik perataan laba. Perataan laba yang tinggi mencerminkan tingginya usaha manajemen untuk meratakan laba yang sebenarnya terjadi sehingga terlihat normal. Hal ini dikarenakan perataan laba adalah tindakan yang dibuat oleh manajemen untuk membuat laba yang terdapat di laporan keuangan terlihat baik, stabil dan sesuai dengan target yang diinginkan perusahaan yang nantinya dapat dipandang oleh stakeholder bahwa perusahaan tersebut memiliki kinerja yang stabil dan baik di setiap periodenya. Salah satu cara untuk melakukan praktik perataan laba dengan merekayasa data penjualan seperti pembuatan penjualan fiktif, pemesanan fiktif, perekayasaan faktur, dan sebagainya. Tidak hanya itu, perataan laba yang tinggi mencerminkan masih kurangnya kejujuran serta transparansi pihak manajemen terhadap penyajian laporan keuangan, sehingga untuk mengantisipasi fraud yang memungkinkan dalam penyajian laporan keuangan stakeholder tersebut harus menganalisis dan mengevaluasi sebelum menggunakan informasi yang terdapat di laporan keuangan perusahaan tersebut. Dikatakan data layak digunakan apabila nilai mean diatas nilai minimum dan standar deviasi mendekati nilai mean. Sehingga dapat disimpulkan bahwa data pada variabel Perataan Laba layak untuk digunakan.

2. Berkaitan dengan variabel profitabilitas yang bejumlah 245 data penelitian variabel profitabilitas (X1) memiliki nilai rata-rata yang menyatakan rerata nilai dari profitabilitas pada seluruh data yang ada sebesar 0,1328 dan standar deviasi yang menampilkan besarnya nilai simpangan baku pada profitabilitas sebesar 0,15706. Adapun nilai minimum dari profitabilitas sebesar 0,01 yang artinya dari seluruh data perusahaan manufaktur yang tercatat di BEI dari tahun 2011-2015, perusahaan STAR di tahun 2015 merupakan perusahaan dengan profitabilitas terkecil yang telah melakukan praktik perataan laba. Sedangkan nilai maksimum dari profitabilitas 0,84 yang artinya dari seluruh data perusahaan manufaktur yang tercatat di BEI dari tahun 2011-2015, perusahaan IPOL di tahun 2013 merupakan perusahaan dengan profitabilitas terbesar yang telah melakukan praktik perataan laba. Profitabilitas yang tinggi mencerminkan besarnya keuntungan yang diperoleh oleh perusahaan di setiap periodenya hal ini karena profitabilitas merupakan keuntungan yang didapat dari hasil pengurangan modal perusahaan dan keputusan kebijakan perusahaan yang biasa kita sebut dengan biaya dan beban. Tidak hanya itu, profitabilitas yang tinggi mencerminkan keefektivan perusahaan dalam mengelola sumber dayanya, sehingga untuk meningkatkan profitabilitas perusahaan tersebut harus efektif dan efisien dalam pengolahan potensi sumber daya yang dimilikinya. Dikatakan data layak digunakan apabila nilai mean diatas nilai minimum dan standar deviasi mendekati nilai mean. Sehingga dapat disimpulkan bahwa data pada variabel profitabilitas layak untuk digunakan.

3. Berkaitan dengan variabel ukuran perusahaan yang bejumlah 245 data penelitian variabel ukuran perusahaan (X2) memiliki nilai rata-rata yang menyatakan rerata nilai dari ukuran perusahaan pada seluruh data yang ada sebesar 0,2863 dan standar deviasi yang menampilkan besarnya nilai simpangan baku pada ukuran perusahaan sebesar 0,01755. Adapun nilai minimum dari ukuran perusahaan sebesar 0,25 merupakan ukuran perusahaan dari perusahaan LMSH tahun 2011 yang artinya dari seluruh data perusahaan manufaktur yang tercatat di BEI dari tahun 2011-2015, perusahaan LMSH di tahun 2011 merupakan perusahaan dengan ukuran perusahaan terkecil yang telah melakukan praktik perataan laba. Sedangkan nilai maksimum dari ukuran perusahaan sebesar 0,33 merupakan ukuran perusahaan dari perusahaan ASII di tahun 2015 yang artinya dari seluruh data perusahaan manufaktur yang tercatat di BEI dari tahun 2011-2015, perusahaan ASII di tahun 2015 merupakan perusahaan yang memiliki ukuran perusahaan paling besar yang telah melakukan praktik perataan laba. Ukuran perusahaan yang besar mencerminkan besarnya aset yang dimiliki oleh perusahaan, hal ini dikarenakan untuk mengukur besarnya perusahaan digunakan rumus $L n$ dari total aset. Tidak hanya itu, ukuran perusahaan yang besar mencerminkan besarnya modal yang dimiliki perusahaan, sehingga untuk meningkatkan modal perusahaan tersebut harus meningkatkan aset dengan menambah modal yang dimilikinya. Salah satu solusinya dengan cara menarik dan meyakinkan investor untuk berinvestasi dengan menampilkan hasil kinerja baik yang tertuang dalam laporan keuangan. Dikatakan data layak digunakan apabila nilai mean diatas nilai minimum dan standar deviasi mendekati nilai mean. Sehingga dapat disimpulkan bahwa data pada variabel ukuran perusahaan layak untuk digunakan.

4. Berkaitan dengan variabel leverage yang bejumlah 245 data penelitian variabel leverage (X3) memiliki nilai ratarata yang menyatakan rerata nilai dari leverage pada seluruh data yang ada sebesar 0,4278 dan standar deviasi yang menampilkan besarnya nilai simpangan baku pada leverage sebesar 0,17758. Adapun nilai minimum dari leverage sebesar 0,10 merupakan leverage dari perusahaan TCID tahun 2011 yang artinya dari seluruh data perusahaan manufaktur yang tercatat di BEI dari tahun 2011-2015, perusahaan TCID di tahun 2011 merupakan perusahaan yang memiliki tingkat leverage paling kecil yang telah melakukan praktik perataan laba. Sedangkan nilai maksimum dari leverage sebesar 0,88 merupakan leverage dari perusahaan JECC tahun 2013 yang artinya dari seluruh data perusahaan manufaktur yang tercatat di BEI dari tahun 2011-2015, perusahaan JECC di tahun 2013 merupakan perusahaan yang memiliki tingkat leverage paling besar yang telah melakukan praktik perataan laba. Leverage yang tinggi mencerminkan tingginya tingkat utang yang ada dalam perusahaan. Hal ini dikarenakan leverage adalah analisis untuk mengukur sejauh mana aktiva perusahaan dibiayai dengan hutang. Tidak hanya itu, leverage yang tinggi mencerminkan tinggi pula resiko yang diterima oleh investor, sehingga untuk meningkatkan kepercayaan investor perusahaan harus mampu menunjukkan perolehan keuntungan yang besar di perusahaan tersebut. Dikatakan data layak digunakan apabila nilai mean diatas nilai minimum dan standar deviasi mendekati nilai mean. 
Sehingga dapat disimpulkan bahwa data pada variabel leverage layak untuk digunakan.

\section{Uji Asumsi Klasik}

\section{a. Uji Normalitas}

Uji normalitas dilakukan untuk mengetahui apakah data yang diperoleh berdistribusi normal atau tidak. Uji normalitas yang dilakukan terhadap sampel dilakukan dengan menggunakan kolmogorov-smirnov test dengan menetapkan derajat keyakinan $(\alpha)$ sebesar 5\%. Uji ini dilakukan pada setiap variabel dengan ketentuan jika secara individual masingmasing variabel memenuhi asumsi normalitas, maka secara simultan variabel-variabel tersebut juga bisa dinyatakan memenuhi asumsi normalitas (Ghozali,2011). Hasil uji normalitas sebagai berikut:

Tabel 2. Hasil Uji Normalitas

\begin{tabular}{ll}
\hline Variabel & Nilai Kolmogorov Keterangan \\
Smirnov
\end{tabular}

\begin{tabular}{lll}
\hline Profitabilitas (X1) & 0.129 & $\begin{array}{l}\text { Berdistribusi } \\
\text { Normal }\end{array}$
\end{tabular}

Ukuran Perusahaan 0.119

(X2)

$\begin{array}{lll}\text { Leverage (X3) } & 0.200 & \begin{array}{l}\text { Berdistribusi } \\ \text { Normal }\end{array} \\ \text { Perataan Laba (Y) } & 0.143 & \begin{array}{l}\text { Berdistribusi } \\ \text { Normal }\end{array}\end{array}$

Sumber :Hasil output SPSS

Berdasarkan Tabel 2 hasil pengujian pada tabel tersebut, dapat diketahui bahwa variabel Profitabilitas (X1) memiliki nilai probabilitas atau signifikansi sebesar 0,129 , variabel Ukuran Perusahaan (X2) memiliki nilai probabilitas atau signifikansi sebesar 0,119 , variable Leverage (X3) memiliki nilai probabilitas atau signifikansi sebesar 0.200 , dan variabel Perataan Laba (Y) memiliki nilai probabilitas atau signifikansi sebesar 0,143. Dapat dikatakan data penelitian normal apabila nilai Kolmogorov Smirnov diatas 0,05 atau $5 \%$ dengan tingkat kepercayaan 95\%. Hasil analisis ini dapat disimpulkan bahwa data sampel dalam penelitian ini berasal dari populasi yang terdistribusi secara normal.

\section{b. Uji Multikolinieritas}

Uji multikoliniearitas merupakan uji asumsi yang dilakukan guna untuk mengetahui bahwa antara variabel-variabel independen dalam suatu model tidak ada hubungannya atau tidak berkorelasi antara satu dan lainnya. Menurut Gujarati (2003). Hasil uji multikolinearitas sebagai berikut :

Tabel 3. Hasil Uji Multikolinieritas

\begin{tabular}{llll}
\hline \multirow{2}{*}{ Model } & \multicolumn{2}{c}{ Collinearity Statistic } & \multirow{2}{*}{ Keterangan } \\
\cline { 2 - 3 } & Tolerance & VIF & \\
\hline $\mathrm{X} 1$ & 0.959 & 1.043 & $\begin{array}{l}\text { tidak terjadi } \\
\text { multikolinieri } \\
\text { tas }\end{array}$ \\
& & &
\end{tabular}

$\begin{array}{lll}\mathrm{X} 2 & 0.965 & 1.036\end{array}$

X3

0.993

1.007

tidak terjadi multikolinieri tas

tidak terjadi multikolinieri tas

\section{Sumber : Hasil output SPSS}

Berdasarkan hasil analisis Collinearity Statistics yang dapat dilihat pada Tabel 3, diketahui bahwa variabel X1 yaitu profitabilitas memiliki nilai VIF sebesar 1,043 dan nilai tolerance sebesar 0,959. Dari hasil tersebut dapat terlihat bahwa profitabilitas memiliki nilai VIF dibawah 10 dan nilai tolerance diatas 0,10. Sehingga dapat disimpulkan pada variabel profitabilitas tidak terjadi multikolinieritas.

Berdasarkan hasil analisis diketahui bahwa variabel $\mathrm{X} 2$ yaitu ukuran perusahaan memiliki nilai VIF sebesar 1,036 dan nilai tolerance sebesar 0,965. Dari hasil tersebut dapat terlihat bahwa profitabilitas memiliki nilai VIF dibawah 10 dan nilai tolerance diatas 0,10 . Sehingga dapat disimpulkan pada variabel ukuran perusahaan tidak terjadi multikolinieritas.

Berdasarkan hasil analisis diketahui bahwa variabel X3 yaitu leverage memiliki nilai VIF sebesar 1,007 dan nilai tolerance sebesar 0,993. Dari hasil tersebut dapat terlihat bahwa profitabilitas memiliki nilai VIF dibawah 10 dan nilai tolerance diatas 0,10. Sehingga dapat disimpulkan pada variabel leverage tidak terjadi multikolinieritas.

Dengan demikian dapat dinyatakan bahwa tidak terjadi hubungan atau multikolinearitas diantara variabel-variabel independen.

\section{c. Uji Heterokedastisitas}

Uji heteroskedasitas adalah pengujian yang dilakukan untuk mengetahui apakah suatu model terdapat varian yang tidak sama dalam semua pengamatan. Penelitian ini menggunakan uji Glejser (Glejser Test) dalam menguji ada tidaknya heteroskedasitas. Pengujian heteroskedasitas dengan uji Glejser dilakukan dengan meregresikan nilai residual dan nilai absolut terhadap seluruh variabel bebas, jika nilai signifikan $>5 \%$ maka tidak terjadi heteroskedasitas (Gujarati, 2003). Hasil uji heteroskedastisitas dapat dilihat pada Tabel 4 berikut:

Tabel 4. Hasil Uji Glejser

\begin{tabular}{lll}
\hline Variabel & Sig & \multicolumn{2}{l}{ Keterangan } \\
\hline Profitabilitas (X1) & 0.199 & $\begin{array}{l}\text { Tidak } \\
\text { Heterokesdatisitas }\end{array}$ \\
& & \multicolumn{2}{l}{ Terjadi } \\
Ukuran & 0.283 & $\begin{array}{l}\text { Tidak } \\
\text { Heterokesdatisitas }\end{array}$ \\
Perusahaan (X2) & & Terjadi \\
Leverage (X3) & 0.958 & $\begin{array}{l}\text { Tidak Terjadi } \\
\text { Heterokesdatisitas }\end{array}$
\end{tabular}

\section{Sumber : Hasil output SPSS}

Berdasarkan Tabel 4 apat diketahui bahwa nilai signifikansi pada variabel profitabilitas sebesar 0,199 , nilai signifikansi pada variabel ukuran perusaahaan sebesar 0,283, dan nilai 
signifikansi pada variabel leverage sebesar 0,958. Dapat dikatakan tidak heterokesdatisitas apabila nilai signifikan diatas 0,05. Dengan demikian, dari hasil tersebut disimpulkan bahwa tidak terjadi heterokesdasitas dari persamaan yang diuji.

\section{d. Uji Autokorelasi}

Uji autokorelasi merupakan suatu keadaaan dimana error yang terjadi antar periode waktu memiliki hubungan, pada data time series umumnya ditemukan masalah autokorelasi ini. Menurut Ghozali (2013), pengujian autokorelasi bertujuan untuk menguji apakah dalam suatu model regresi linier ada korelasi antara kesalahan pengganggu pada periode $\mathrm{t}$ dengan kesalahan pada periode sebelumnya (t-1) dan dapat dilakukan dengan menggunakan uji Durbin Watson (DW test). Metode ini digunakan untuk mengukur autokorelasi tingkat satu (first order autocorrelation). Hasil uji autokorelasi sebagai berikut:

Tabel 5. Hasil Uji Autokorelasi

\begin{tabular}{|c|c|c|c|}
\hline Variabel & $\begin{array}{l}\text { Nilai } \\
\text { Watson }\end{array}$ & Durbin- & Keterangan \\
\hline Residual & 2.162 & & $\begin{array}{l}\text { Tidak } \\
\text { auotokorelas }\end{array}$ \\
\hline
\end{tabular}

\section{Sumber : Hasil output SPSS}

Berdasarkan hasil pengujian pada Tabel 5dapat diketahui bahwa nilai Durbin-Watson adalah 2.162. Berdasarkan tabel Durbin-Watson dengan jumlah sampel (n) 245, dan variabel independen (k) 3. Maka didapat nilai du $=1,799$, sehingga dari nilai DW sebesar 2,162 terletak diantara du $<\mathrm{dw}<4$-du yaitu $1,799<2,162<2,2727$. Dengan demikian menunjukkan bahwa pada model regresi tidak terjadi masalah autokorelasi.

\section{Uji Hipotesis}

\section{a. Analisis Regresi Linier Berganda}

Menurut Ghozali (2011) analisis regresi berganda digunakan untuk mengukur pengaruh antara lebih dari satu variabel independen atau variabel bebas terhadap variabel terikat. Hasil analisis regresi linier berganda sebagai berikut:

Tabel 6. Hasil Analisis Regresi Linier Berganda

\begin{tabular}{llll}
\hline Variabel & $\begin{array}{l}\text { Koefisien } \\
\text { Regresi }\end{array}$ & Sig. & Keterangan \\
\hline Konstan & 0.104 & - & - \\
$\begin{array}{l}\text { Profitabilitas } \\
(\mathrm{X} 1)\end{array}$ & 0.230 & 0,000 & Signifikan \\
$\begin{array}{l}\text { Ukuran } \\
\begin{array}{l}\text { Perusahaan } \\
\text { (X2) }\end{array}\end{array}$ & 1.211 & 0,003 & Signifikan \\
$\begin{array}{l}\text { Leverage } \\
\text { (X3) }\end{array}$ & 0.098 & 0,014 & Signifikan \\
\hline
\end{tabular}

Sumber : Hasil output SPSS
Berdasarkan Tabel 6 hasil tersebut dapat diperoleh persamaan regersi linier berganda sebagai berikut:

$\mathrm{Y}=0.104+0.230(\mathrm{X} 1)+1.211(\mathrm{X} 2)+0.098(\mathrm{X} 3)+e$

a. Nilai Konstanta

Dari persamaan tersebut didapatkan arti bahwa nilai konstanta merupakan nilai tetap yang mempengaruhi besarnya $Y$. Di dalam persamaan ini menunjukkan jika X1yaitu profitabilitas, X2 yaitu ukuran perusahaan, dan X3 yaitu leverage suatu perusahaan tidak mengalami penambahan atau pengurangan, maka nilai $\mathrm{Y}$ yaitu perataan laba tetap sebesar nilai konstanta. Jika X1, X2, dan X3 pada perusahaan mengalami kenaikkan maka akan menambah nilai konstanta yang berarti akan mempengaruhi kenaikan pada $\mathrm{Y}$. Begitu pula apabila X1, X2, dan X3 mengalami penurunan maka akan mengurangi nilai konstanta yang berarti akan mempengaruhi penurunan nilai $\mathrm{Y}$.

b. Profitabilitas (X1)

Nilai signifikan profitabilitas sebesar 0,000. Dikatakan berpengaruh apabila nilai signifikan dibawah 0,05. Dari persamaan tersebut didapatkan nilai koefisien bertanda positif, yang berarti akan berpengaruh positif pula pada kenaikan nilai perataan laba. Setiap kenaikan pada nilai profitabilitas, maka variabel perataan laba akan naik sebesar nilai profitabilitas. Sebaliknya jika nilai profitabilitas mengalami penurunan, maka variabel perataan laba akan turun sebesar nilai profitabilitas. Sehingga dapat disimpulkan bahwa profitabilitas mempunyai hubungan yang berpengaruh terhadap variabel perataan laba.

\section{c. Ukuran Perusahaan (X2)}

Nilai signifikan ukuran perusahaan sebesar 0,003. Dikatakan berpengaruh apabila nilai signifikan dibawah 0,05. Dari persamaan tersebut didapatkan nilai koefisien bertanda positif, yang berarti akan berpengaruh positif pula pada kenaikan nilai perataan laba. Setiap kenaikan pada nilai ukuran perusahaan, maka variabel perataan laba akan naik sebesar nilai ukuran perusahaan. Sebaliknya jika nilai ukuran perusahaan mengalami penurunan, maka variabel perataan laba akan turun sebesar nilai ukuran perusahaan. Sehingga dapat disimpulkan bahwa ukuran perusahaan mempunyai hubungan yang berpengaruh terhadap variabel perataan laba.

\section{d. Leverage (X3)}

Nilai signifikan leverage sebesar 0,014. Dikatakan berpengaruh apabila nilai signifikan dibawah 0,05. Dari persamaan tersebut didapatkan nilai koefisien bertanda positif, yang berarti akan berpengaruh positif pula pada kenaikan nilai perataan laba. Setiap kenaikan pada leverage, maka variabel perataan laba akan naik sebesar nilai leverage. Sebaliknya jika nilai leverage mengalami penurunan, maka variabel perataan laba akan turun sebesar nilai leverage. Sehingga dapat disimpulkan bahwa leverage mempunyai hubungan yang berpengaruh terhadap variabel perataan laba.

\section{b. Uji F}

Uji F adalah uji kelayakan model yang harus dilakukan dalam analisis linier. Jika uji $\mathrm{F}$ tidak signifikan, maka tidak disarankan untuk melakukan uji $\mathrm{t}$ atau uji parsial. Uji $\mathrm{F}$ dilakukan dengan menggunakan tabel ANOVA yang 
bertujuan untuk menguji kelayakan model regresi yang digunakan, sehingga nilai koefisiensi regresi secara bersamasama dapat diketahui dengan ketentuan bahwa jika $p$ value $<$ $(\alpha)=0,05$ dan $\mathrm{F}_{\text {hitung }}>\mathrm{F}_{\text {tabel }}$ berarti model tersebut signifikan dan bisa digunakan untuk menguji hipotesis. Dengan tingkat kepercayaan $(\alpha)$ untuk pengujian hipotesis adalah $95 \%$ atau $(\alpha)=0,05$ (Ghozali, 2011).

Hasil dari uji $\mathrm{F}$ dapat dilihat pada Tabel 7 berikut :

Tabel 7. Hasil Uji F

\begin{tabular}{lll}
\hline Variabel & Nilai Annova & Sig. \\
\hline Residual & 11,483 & $0,000^{\mathrm{b}}$
\end{tabular}

\section{Sumber : Hasil output SPSS}

Berdasarkan hasil perhitungan uji $\mathrm{F}$ yang terlihat pada Tabel 7 diperoleh nilai $\mathrm{F}_{\text {hitung }}$ sebesar 11,483 lebih besar daripada $\mathrm{F}_{\text {tabel }}$ sebesar 2,6 ( $\left.\mathrm{F}_{\text {hitung }}>\mathrm{F}_{\text {tabel }}\right)$ dan nilai signifikansi sebesar 0,000 lebih kecil dari nilai 0,05 (Sig. < 0,05). Dari analisis tersebut dapat disimpulkan bahwa model regresi layak digunakan untuk menguji hipotesis dengan tingkat kepercayaan 95\%. Dengan demikian dapat disimpulkan ada pengaruh antara variabel bebas $\mathrm{X}$ terhadap variabel terikat $\mathrm{Y}$.

\section{c. Uji t}

Uji t digunakan untuk menguji signifikan hubungan antara variable $\mathrm{X}$ dan $\mathrm{Y}$, apakah variable $\mathrm{X} 1, \mathrm{X} 2$, dan X3 (profitabilitas, ukuran perusahaan, dan leverage) benar-benar berpengaruh terhadap variable Y (perataan laba). Dengan menggunakan tingkat signifikasi 0,05 (5\%), dapat diketahui pengaruh masing-masing variable independen secara parsial terhadap variable dependen. Jika nilai signifikasi $>0,05$ maka tidak ada pengaruh variable independen terhadap variable dependen. Sedangkan jika terjadi sebaliknya, yaitu nilai signifikasi $<0,05$ maka variable independen berpengaruh terhadap variable dependen. Hasil uji t sebagai berikut:

Tabel 8. Hasil Uji t

\begin{tabular}{lc}
\hline \multicolumn{1}{c}{ Variabel } & Sig \\
\hline Profitabilitas (X1) & 0.000 \\
Ukuran Perusahaan (X2) & 0.003 \\
Leverage (X3) & 0.014
\end{tabular}

\section{Sumber : Hasil output SPSS}

Berdasarkan Tabel 8 dapat diketahui besar dari pengaruh masing-masing variabel independen terhadap variabel dependen sebagai berikut :

1. Pengaruh variabel Profitabilitas (X1) terhadap variabel Perataan Laba (Y)

Berdasarkan Tabel 8 dapat dilihat bahwa tingkat probabilitas ( $\alpha$ ) adalah 0,000. Hal ini berarti Profitabilitas (X1) berpengaruh signifikan terhadap Perataan Laba (Y).

2. Pengaruh variabel Ukuran Perusahaan (X2) terhadap variabel Perataan Laba (Y)
Berdasarkan Tabel 8 dapat dilihat bahwa tingkat probabilitas ( $\alpha$ ) adalah 0,003. Hal ini berarti Ukuran Perusahaan (X2) berpengaruh signifikan terhadap Perataan Laba (Y).

3. Pengaruh variabel Leverage (X3) terhadap variabel Perataan Laba (Y)

Berdasarkan Tabel 8 dapat dilihat bahwa tingkat probabilitas $(\alpha)$ adalah 0,014 . Hal ini berarti Leverage (X3) berpengaruh signifikan terhadap Perataan Laba (Y).

Berdasarkan analisis yang dilakukan, dapat dinyatakan bahwa terdapat hubungan antara variabel independen dan variabel dependen.

\section{d. Uji Koefisien Determinasi $\left(\mathbf{R}^{\mathbf{2}}\right)$}

Menurut Ghozali (2011), koefisien determinasi $\left(\mathrm{R}^{2}\right)$ pada intinya mengukur seberapa jauh model dalam menerangkan variasi variabel dependen. Nilai koefisien determinasi adalah antara nol dan satu. Nilai $\mathrm{R}^{2}$ yang kecil berarti kemampuan variabel-variabel independen dalam menjelaskan variasi variabel dependen aman terbatas. Nilai yang mendekati satu berarti variabel variabel independen memberikan hampir sama informasi yang dibutuhkan untuk memprediksi variasi dependen. Hasil uji $\mathrm{R}^{2}$ sebagai berikut :

Tabel 9. Hasil Uji R2

\begin{tabular}{llll}
\hline Variabel & R Square & $\begin{array}{l}\text { Adjusted } \\
\text { Square }\end{array}$ & R \\
\hline 1 & 0,525 & 0,514
\end{tabular}

Sumber : Hasil output SPSS

Berdasarkan Tabel 9 menunjukan model memiliki nilai Adjusted $R$ Square sebesar 0,514. Hal ini berarti variabel terikat Perataan Laba (Y) dipengaruhi oleh Profitabilitas (X1), Ukuran Perusahaan (X2), dan Leverage (X3) sebesar $51,4 \%$. Nilai tersebut menunjukkan bahwa secara keseluruhan variabel bebas mempengaruhi 51,4\% variabel terikat sedangkan sisanya 48,6\% (100\%-51,4\%) dipengaruhi oleh variabel lain diluar model.

\section{Pembahasan}

\section{Profitabilitas Terhadap Perataan Laba}

Variabel Profitabilitas (X1) berpengaruh signifikan terhadap Perataan Laba, hal ini ditunjukkan dengan koefisien regresi sebesar 0,230 dan nilai signifikansi sebesar 0,000 yang berada di bawah $0,05(0,000<0,05)$ sehingga disimpulkan bahwa profitabilitas berpengaruh signifikan terhadap perataan laba. Hal ini berarti semakin tinggi profitabilitas yang ditunjukkan melalui laba yang dimiliki perusahaan, maka mampu memberikan pengaruh untuk melakukan praktik perataan laba pada perusahaan tersebut. Penelitian ini membuktikan bahwa profitabilitas memberikan pengaruh dalam praktik perataan laba.

\section{Ukuran Perusahaan Terhadap Perataan Laba}

Variabel Ukuran Perusahaan (X2) berpengaruh signifikan terhadap Perataan Laba, hal ini ditunjukkan dengan koefisien regresi sebesar 1,211 dan nilai signifikansi sebesar 0,003 yang berada di bawah 0,05 $(0,003<0,05)$ sehingga disimpulkan bahwa Ukuran Perusahaan berpengaruh signifikan terhadap Perataan Laba. Hal ini berarti semakin 
besar ukuran perusahaan yang ditunjukkan melalui besarnya total aset yang dimiliki perusahaan, maka memberikan pengaruh untuk dilakukannya praktik perataan laba. Diperolehnya pengaruh yang signifikan untuk ukuran perusahaan terhadap perataan laba menunjukkan bahwa ukuran perusahaan memungkinkan sebagai faktor penunjang dilakukannya perataan laba. Terjadi demikian karena perusahaan besar memiliki total aset yang besar pula, total aset yang besar didapat dari modal yang besar pula. Untuk memperoleh modal besar harus dapat menyakinkan investor terhadap kinerja perusahaan, sehingga memungkinkan perusahaan melakukan praktik perataan laba.

\section{Leverage Terhadap Perataan Laba}

Variabel Leverage (X3) berpengaruh signifikan terhadap Perataan Laba, hal ini ditunjukkan dengan koefisien regresi sebesar 0,098 dan nilai signifikansi sebesar 0,014 yang berada di bawah $0,05(0,014<0,05)$ sehingga disimpulkan bahwa Leverage berpengaruh signifikan terhadap Perataan Laba. Hal ini membuktikan bahwa leverage berpengaruh terhadap praktik perataan laba. Dengan semakin tingginya tingkat utang yang dimiliki oleh perusahaan, maka mendorong manajemen untuk melakukan manipulasi laba untuk meningkatkan citra dan reputasi perusahaan di mata stakeholder agar investor tetap mau berinvestasi di perusahaan tersebut.

\section{Simpulan}

Hasil pengujian regresi berganda atas pengaruh Profitabilitas terhadap Perataan Laba menunjukkan hubungan yang signifikan, ini membuktikan bahwa Profitabilitas yang tinggi mampu memberikan pengaruh untuk melakukan tindakan perataan laba.

Pengaruh Ukuran Perusahaan terhadap Perataan Laba menunjukkan hubungan yang signifikan, ini membuktikan bahwa Ukuran Perusahaan yang besar mampu memberikan pengaruh untuk melakukan tindakan perataan laba.

pengaruh Leverage terhadap Perataan Laba menunjukkan hubungan yang signifikan. Ini membuktikan bahwa Leverage yang tinggi mampu memberikan pengaruh melakukan tindakan perataan laba.

\section{Referensi}

Alwiyah dan Charis Solihin. 2015. Pengaruh Income Smoothing Terhadap Earning Response pada Perusahaan Manufaktur yang Listing di BEI. Jurnal Performance Bisnis dan Akuntansi. Vol 5 (2) : 80-96.

Belkaoui. 2007. Accounting Theory. Jakarta : Salemba Empat.

Brigham, Eugene F dan Joel F. Houston. 2013. Dasar-dasar Manajemen Keuangan. Jakarta : Salemba Empat.

Ghazali, Imam. 2011. Aplikasi Analisis Multivariate dengan program IBM SPSS 19. Semarang : Universitas Dipenogoro.

Gujarati, Damodar. 2003. Ekonomi Dasar. Jakarta : Erlangga.

Sawir, Agnes. 2004. Analisis Kinerja Keuangan dan Perencanaan Keuangan Perusahaan. Jakarta : PT. Gramedia Pustaka Utama

Wijoyo, Dewi Sari. 2014. Variabel-Variabel yang Mempengaruhi Praktik Perataan Laba pada Perusahaan Manufaktur yang Publik. Jurnal Bisnis dan Akuntansi. Vol 16 (1) :37-45 